\title{
THE CATION EXCHANGE CAPACITY OF THE GREEK ZEOLITIC ROCKS
}

\section{Filippidis A. ${ }^{1}$, Kantiranis N. ${ }^{1}$, Stamatakis M. ${ }^{2}$, Drakoulis A. ${ }^{1}$, and Tzamos E. ${ }^{1}$}

${ }^{l}$ Aristotle University of Thessaloniki, Faculty of Sciences, School of Geology, Department of Mineralogy-Petrology-Economic Geology, anestis@geo.auth.gr, kantira@geo.auth.gr, alexdr@geo.auth.gr,tzamos@geo.auth.gr

${ }^{2}$ National and Kapodistrian University of Athens, Faculty of Geology and Geoenvironment, Department of Economic Geology and Geochemistry, stamatakis@geol.uoa.gr

\begin{abstract}
Forty two zeolitic rock samples, from the Prefectures of Evros, Rhodope, Samos and Cyclades, have been investigated for their cation exchange capacity (CEC, in meq/100g) and the mineralogical composition (wt.\%), using the Ammonium Acetate Saturation method and Powder X-ray Diffraction method, respectively. HEU-type zeolite (heulandite-clinoptilolite) was found in Petrota area (43-89 wt.\%, CEC 101217), Samos island (34-91 wt.\%, CEC 93-217), Pentalofos area (68-74 wt.\%, CEC 124-202), Metaxades area (47-64 wt.\%, CEC 119-140) and Thira island (33 wt.\%, CEC 118). Mordenite was found in Samos island (64 wt.\%, CEC 150), Polyegos island (61 wt.\%, CEC 136), Thira island (56 wt.\%, CEC 130), Milos island (45 wt.\%, CEC 97), Kimolos island (30 wt.\%, CEC 96) and Feres area (5 wt.\%, CEC 22). Analcime was found in Samos island (27-71 wt.\%, CEC 104-285) and Darmeni area (16 wt.\%, CEC 62). Chabazite was found in Samos island (66 wt.\%, CEC 243). HEU-type zeolite+mordenite were found in Feres area (45-74 wt.\%, CEC 132-209), Samos island (81 wt.\%, CEC 184), Thira island (72 wt.\%, CEC 177), Polyegos island (66 wt.\%, CEC 153) and Skaloma area (51-60 wt.\%, CEC 126-143). HEUtype zeolite+phillipsite were found in Samos island (47 wt.\%, CEC 170) and HEUtype zeolite+analcime were found in Samos island (55 wt.\%, CEC 129). The CEC of the zeolitic rocks show positive correlations with the type of zeolite and the microporous minerals (zeolites + micas + clay minerals) content, mainly affected by the zeolites and to lesser extent by micas and clay minerals.
\end{abstract}

Key words: Natural zeolites, Evros, Rhodope, Samos, Cyclades, tuffs.

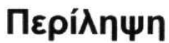

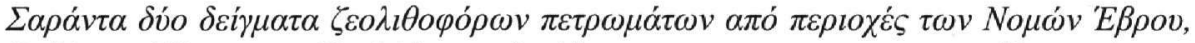

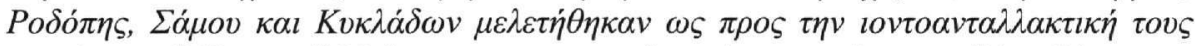

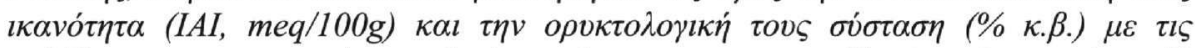

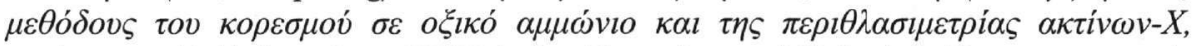

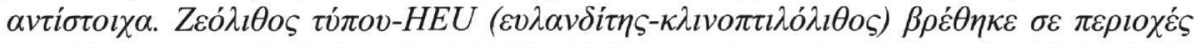

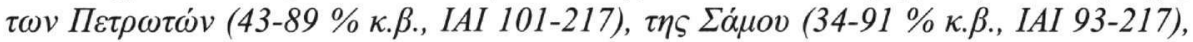

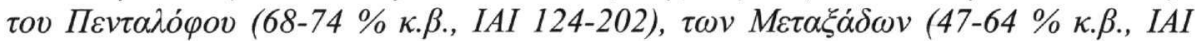

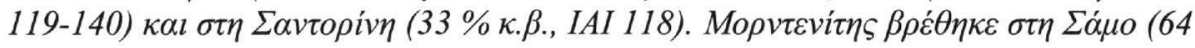




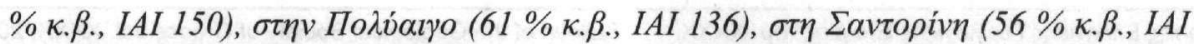

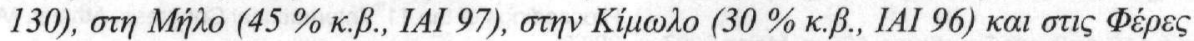

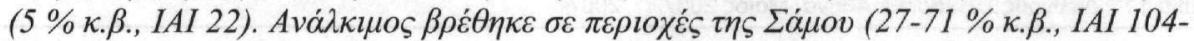

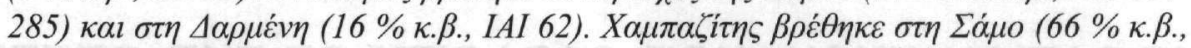

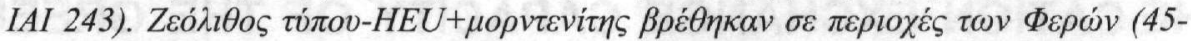

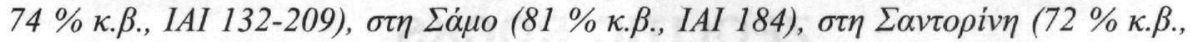

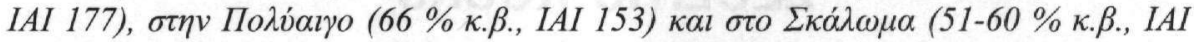

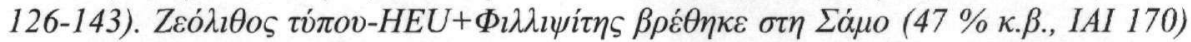

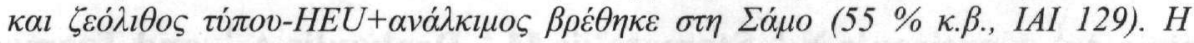

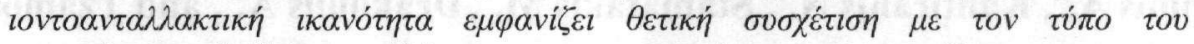

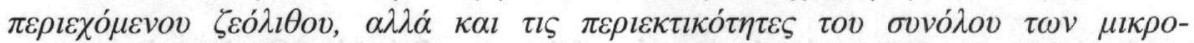

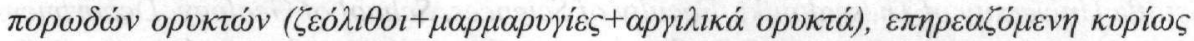

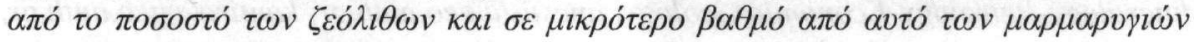

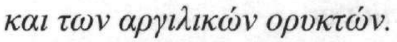

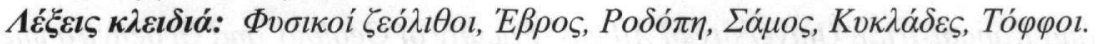

\section{Introduction}

Zeolite occurrences are widespread in Greece and HEU-type zeolites (Heulandite-Clinoptilolite) are the most common types (Kantiranis et al. 2006). Numerous industrial, agricultural and environmental applications have been proposed for the zeolitic rocks of Greece (eg., Kitsopoulos and Dunham 1994, 1996, Misaelides et al. 1994, 1995a, 1995b, Symeopoulos et al. 1996, Filippidis et al. 1997, 2006, Fragoulis et al. 1997, Haiduti 1997, Tserveni-Gousi et al. 1997, Sikalidis 1998, Yannakopoulos et al. 1998, 2000, Filippidis and Kassoli-Fournaraki 2000a, 2000b, 2002, Zorpas et al., 2000a, 2000b, Marantos et al. 2001, Moirou et al. 2001, Vlessidis et al. 2001, Kyriakis et al. 2002, Papaioannou et al. 2002a, 2002b, Inglezakis and Grigoropoulou 2003, Inglezakis et al. 2003, Katranas et al. 2003, Krestou et al. 2003, Perraki et al. 2003, Papadopoulos et al. 2004, Deligiannis et al. 2005, Warchol et al. 2006). The cation exchange capacity of zeolitic rocks from Pentalofos area (Arvanitidis 1998, Stamatakis et al. 2001, Christidis et al. 2003, Perraki and Orfanoudaki 2004), Metaxades area (Marantos et al. 1989; Stamatakis et al. 2001), Dadia-Lefkimi area (Skarpelis et al. 1993), Feres area (Stamatakis et al. 2001), Polyegos and Thira islands (Kitsopoulos 1997b) has been reported, but without quantitative values for the zeolite or the microporous mineral percentage contained in the rocks.

In the present paper the cation exchange capacity is correlated to the zeolite percentage and type, contained in the Greek zeolitic rocks. In particular, 42 zeolitic samples have been collected from different locations in the Prefectures of Evros, Rhodope, Samos and Cyclades. Twenty five related values given by different authors (Marantos and Perdikatsis 1994, Marantos 2004, Kantiranis et al . 2004a, Filippidis, 2005, Filippidis and Kantiranis 2005, 2007, Filippidis et al. 2005) have been also used for the above mentioned correlations.

\section{Materials and Methods}

The geology, geochemistry, mineralogy and genesis of the Greek zeolitic rocks are presented and discussed by several authors, for Evros Prefecture (eg., Tsirambides et al., 1989, 1993, Kirov et al. 1990, Tsolis-Katagas and Katagas 1990, Tsirambides 1991, Filippidis 1993, Koutles et al. 1995, Stamatakis et al. 1998, Hall et al. 2000, Kassoli-Fournaraki et al. 2000, Barbieri et al. 2001), for Rhodope Prefecture (Marantos et al. 1997, 2001), for Samos Prefecture (Stamatakis 1989a, 1989b, Pe-Piper and Tsolis-Katagas 1991, Hall and Stamatakis 1992) and for Cyclades Prefecture (TsolisKatagas and Katagas 1989, Hall et al. 1994, Stamatakis et al. 1996, Fragoulis et al. 1997, Kitsopoulos 1997a, Drakoulis et al. 2005).

The approximate location of the studied zeolitic samples are shown in Figure 1, while the precise location are given in Tables 1,2, 3 and 4 . 

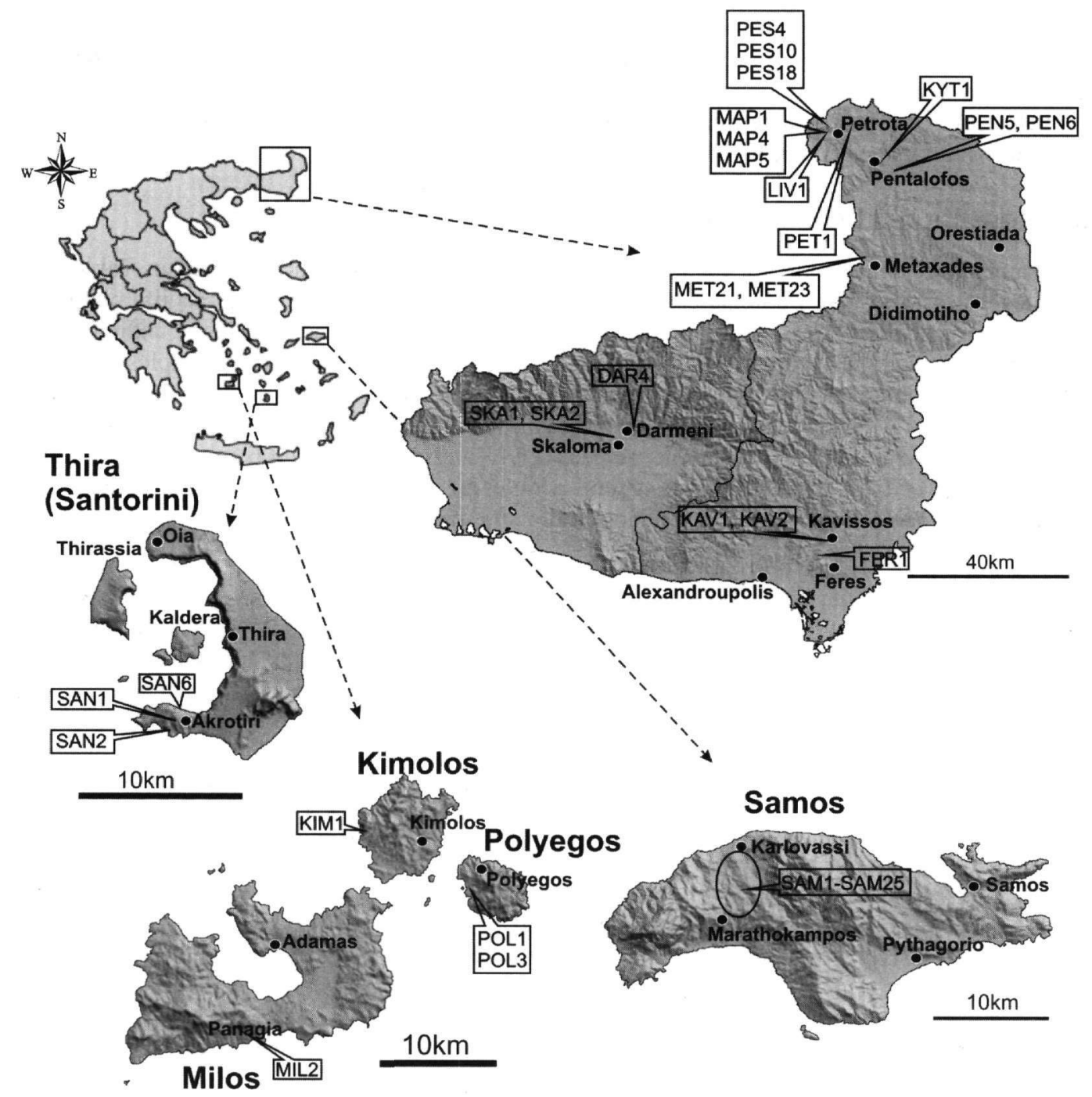

Figure 1 - Location of the studied Greek zeolitic rock samples

Each representative sample of the collected zeolitic tuffs was separated in two equal parts: the first, ground in grain-size $<63 \mu \mathrm{m}$, was used for the investigation of the mineralogical composition, while the second, ground in grain-size $<125 \mu \mathrm{m}$, was used in the experiments for the determination of their ammonium exchange capacity.

Mineralogical composition was determined using the X-Ray Powder Diffraction method (XRPD). XRPD was performed using a Philips PW 1710 diffractometer with Ni-filtered $\mathrm{CuK} \alpha$ radiation. The samples were scanned over the $3-63^{\circ} 2 \theta$ at a scanning speed of $1.2 \%$ min. Semi-quantitative estimates of the abundance of the mineral phases were derived from the XRPD data, using the intensity of certain reflections, the density and the mass absorption coefficient for $\mathrm{CuK} \alpha$ radiation for the minerals present. Then results were corrected using standard mixtures of minerals (external standards) scanned under the same conditions. The semi-quantitative estimation of the percentage of total amorphous material was achieved by comparing the area of each broad background hump which represented the amorphous material in each sample with the analogous area of standard 
mixtures of minerals with different contents of natural amorphous material, scanned under the same conditions (Kantiranis et al. 2004b, Drakoulis et al. 2005).

The ammonium ion is most commonly used for CEC testing of materials and the results therefore are referred to as ammonium exchange capacity. The ammonium cation-exchange capacity of the studied zeolitic tuffs was determined according to the Ammonium Acetate Saturation (AMAS) method (Kantiranis et al. 2004a, Drakoulis et al. 2005).

\section{Results and Discussion}

The mineralogical composition of the studied zeolitic rock samples is presented in Tables 1-4. Zeolites, micas and clay minerals constitute the microporous minerals of the zeoliferous rocks. Five types of zeolites were identified: HEU-type, mordenite, analcime, phillipsite and chabazite. HEU-type (Heulandite-Clinoptilolite) was found in the majority of the studied samples (22 out of 42), while mordenite and analcime were found in fewer samples (6 and 4 out of 42 , respectively). HEU-type+mordenite were found in 7 samples, while HEU-type+analcime, HEU-type+ phillipsite and chabazite were found in one sample, respectively. Kantiranis et al. (2006) studying the thermal characteristics of the Greek HEU-type natural zeolites in relation to their chemical composition, distinguished their HEU-type species (clinoptilolite, intermediate heulandite and heulandite).

The percentage in HEU-type zeolites varies widely between $18 \mathrm{wt} \%$ and $91 \mathrm{wt} . \%$, whereas the percentage of mordenite varies between $5 \mathrm{wt} . \%$ and $64 \mathrm{wt} . \%$. Analcime varies between $16 \mathrm{wt} . \%$ and 71 wt.\%. Phillipsite and chabazite were determined in percentages 29 wt.\% and 66 wt.\%, respectively. In addition, micas, clays, quartz, cristobalite, tridymite, feldspars, calcite and amphibole were also identified. Also, amorphous material was detected in 14 samples, ranging between $2 \mathrm{wt} . \%$ and $24 \mathrm{wt} . \%$. Several researchers in their individual sampling of zeoliferous rocks from near-about the same locations and after a plethora of experimental techniques rendered similar or approximate or different results concerning the mineralogical composition and the CEC of the zeolitic rocks (Tables 1-4).

The CEC of the zeolitic rocks mainly depends on the type and content of the zeolite, as the most typical microporous minerals. A very good positive correlation is observed between CEC and the HEU-type zeolite content (Fig. 2). The same good correlation exists between the CEC and the mordenite, HEU-type + mordenite and analcime contents (Figs 3-5). A general positive correlation exists between CEC and the total zeolite content (Fig. 6). The differences in the CEC values observed in the different zeolitic rocks, depends mainly on their content but also on the type of zeolite. The ion exchange capacity is a function of the specific crystal structure of each zeolite species, and its framework and cationic composition. It should be noted, that the typical ion exchange capacity, calculated from the unit-cell formula for pure minerals, is higher: 454 meq $/ 100 \mathrm{~g}$ for analcime, $387 \mathrm{meq} / 100 \mathrm{~g}$ for phillipsite, $381 \mathrm{meq} / 100 \mathrm{~g}$ for chabazite, $291 \mathrm{meq} / 100 \mathrm{~g}$ for heulandite, $254 \mathrm{meq} / 100 \mathrm{~g}$ for clinoptilolite and $229 \mathrm{meq} / 100 \mathrm{~g}$ for mordenite (Holmes 1994).

The CEC values are also affected to a lesser extent, by the other microporous minerals (micas + clays) contained in the zeolitic rocks. A positive correlation between the CEC and the total microporous minerals (zeolites + micas + clay minerals) is also observed (Fig. 7). The same is also observed between the CEC and total microporous minerals + amorphous material (Fig. 8), since amorphous material includes anionic charges that are responsible for the sorption ability of amorphous materials. It should be noted that the amorphous content ranges from 2 to 29 wt.\% (Tables 1-4) and that the sorption ability of natural amorphous materials depends on their chemistry (Drakoulis et al. 2005). 
Table 1 - Semi-quantitative mineralogical composition (wt.\%) and cation exchange capacity (CEC, meq/100g) of Evros Prefecture zeolitic rocks.

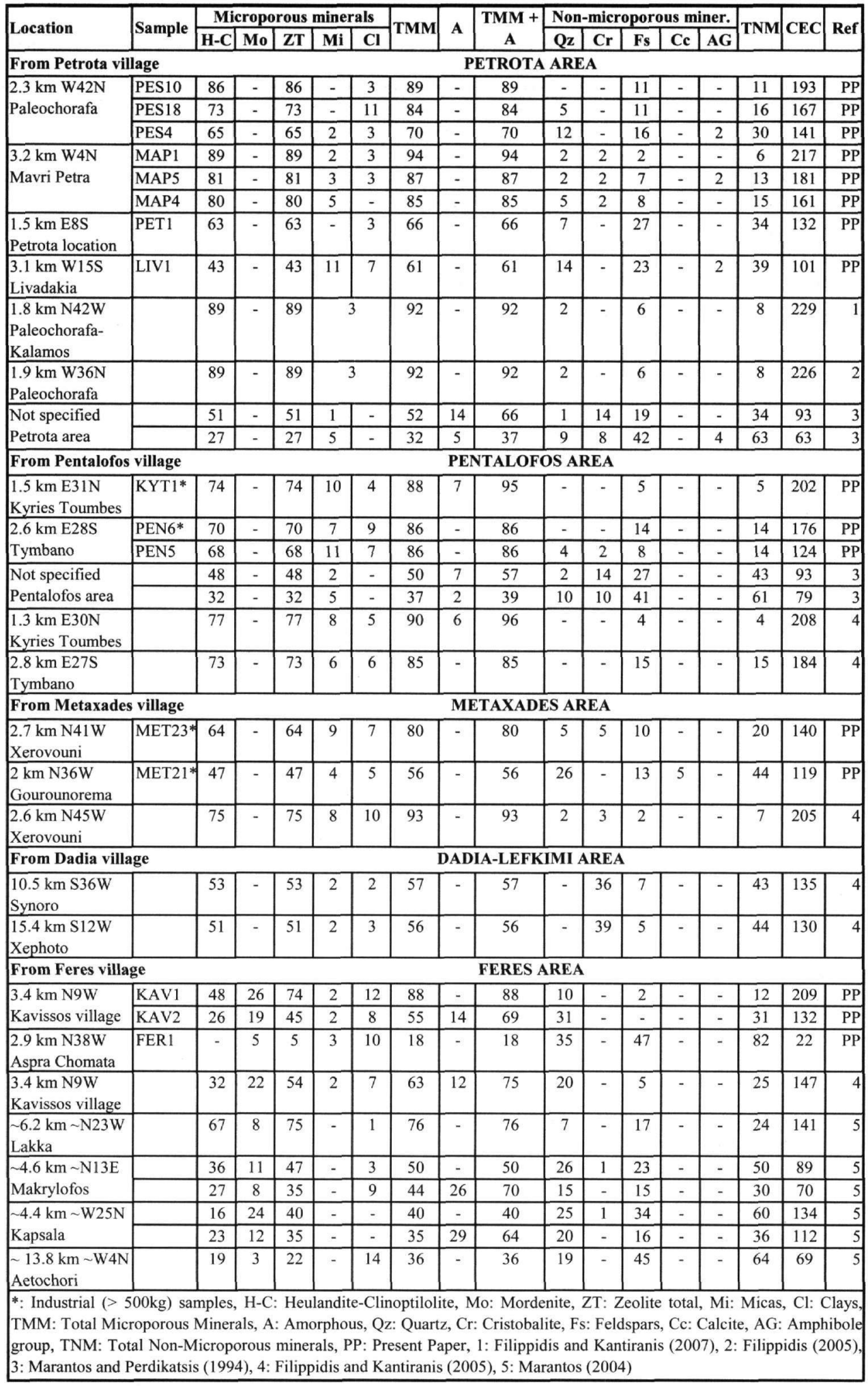


Table 2 - Semi-quantitative mineralogical composition (wt.\%) and cation exchange capacity (CEC, meq/100g) of Rhodope Prefecture zeolitic rocks.

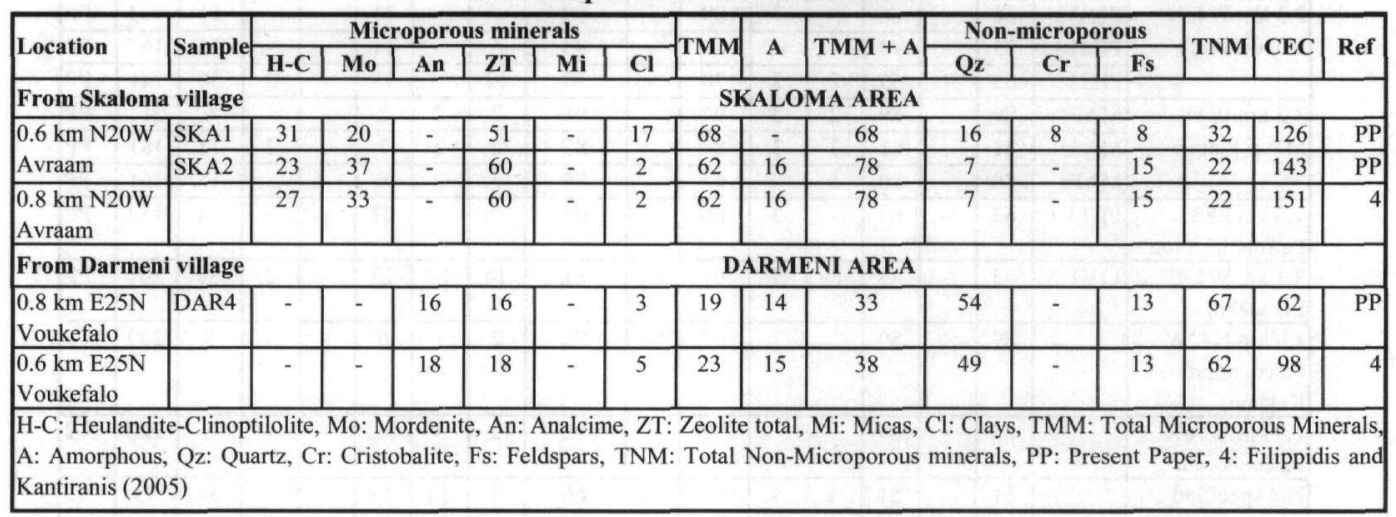

Table 3 - Semi-quantitative mineralogical composition (wt.\%) and cation exchange capacity (CEC, meq/100g) of Samos Prefecture zeolitic rocks.

\begin{tabular}{|c|c|c|c|c|c|c|c|c|c|c|c|c|c|c|c|c|c|}
\hline \multirow{2}{*}{ Location } & \multirow{2}{*}{ Sample } & \multicolumn{8}{|c|}{ Microporous minerals } & \multirow{2}{*}{ TMM } & \multirow{2}{*}{$\mathbf{A}$} & \multirow{2}{*}{$\mathbf{T M M}+\mathbf{A}$} & \multicolumn{2}{|c|}{\begin{tabular}{|l|} 
Non-microporous \\
\end{tabular}} & \multirow{2}{*}{ TNM } & \multirow{2}{*}{ CEC } & \multirow{2}{*}{ Ref } \\
\hline & & \begin{tabular}{|l|l|}
$\mathbf{H}-\mathrm{C}$ \\
\end{tabular} & Mo & An & $\mathbf{P h}$ & Ch & $\mathbf{Z T}$ & $\mathbf{M i}$ & $\mathbf{C l}$ & & & & $\mathbf{Q z}$ & Fs & & & \\
\hline \multicolumn{8}{|c|}{ From Marathokambos village } & \multicolumn{10}{|c|}{ KARLOVASSI - MARATHOKAMBOS AREA } \\
\hline $5.3 \mathrm{~km} \mathrm{~N} 25 \mathrm{E}$ & SAM22 & 91 & - & - & - & - & 91 & 4 & - & 95 & - & 95 & - & 5 & 5 & 213 & PP \\
\hline $3.6 \mathrm{~km} \mathrm{E34N}$ & SAM17 & 86 & - & - & - & - & 86 & 4 & 4 & 94 & - & 94 & - & 6 & 6 & 217 & PP \\
\hline $2.1 \mathrm{~km} \mathrm{E} 32 \mathrm{~N}$ & SAM21 & 73 & - & - & - & - & 73 & 12 & 4 & 89 & - & 89 & 4 & 7 & 11 & 187 & PP \\
\hline $3.5 \mathrm{~km} \mathrm{E} 29 \mathrm{~N}$ & SAM 23 & 65 & - & - & - & - & 65 & 10 & 6 & 81 & - & 81 & - & 19 & 19 & 159 & PP \\
\hline $2.9 \mathrm{~km} \mathrm{~N} 2 \mathrm{E}$ & SAM 24 & 57 & - & - & - & - & 57 & 14 & 6 & 77 & - & 77 & - & 23 & 23 & 143 & PP \\
\hline $4.6 \mathrm{~km} \mathrm{E36N}$ & SAM18 & 55 & - & - & - & - & 55 & 6 & 21 & 82 & - & 82 & - & 18 & 18 & 135 & PP \\
\hline $4.6 \mathrm{~km}$ E38N & SAM19 & 34 & - & - & - & - & 34 & 24 & 4 & 62 & 8 & 70 & - & 30 & 30 & 112 & PP \\
\hline $5.3 \mathrm{~km} \mathrm{~N} 20 \mathrm{E}$ & SAM7 & 34 & - & - & - & - & 34 & 10 & 27 & 71 & 9 & 80 & 4 & 16 & 20 & 93 & PP \\
\hline $2.0 \mathrm{~km} \mathrm{~N} 45 \mathrm{E}$ & SAM1 & 60 & 21 & - & - & - & 81 & 4 & 9 & 94 & - & 94 & 3 & 3 & 6 & 184 & $\mathrm{PP}$ \\
\hline $4.5 \mathrm{~km} \mathrm{E}$ & SAM 15 & - & 64 & - & - & - & 64 & - & - & 64 & 24 & 88 & - & 12 & 12 & 150 & PP \\
\hline $6.6 \mathrm{~km} \mathrm{~N} 15 \mathrm{E}$ & SAM4 & - & - & 71 & - & - & 71 & 5 & 2 & 78 & 10 & 88 & 4 & 8 & 12 & 285 & PP \\
\hline $5.0 \mathrm{~km} \mathrm{~N} 21 \mathrm{E}$ & SAM14 & - & - & 35 & - & - & 35 & 3 & 33 & 71 & - & 71 & - & 29 & 29 & 169 & $\mathrm{PP}$ \\
\hline $5.3 \mathrm{~km} \mathrm{~N} 20 \mathrm{E}$ & SAM6 & - & - & 27 & - & - & 27 & 10 & 27 & 64 & 7 & 71 & 5 & 24 & 29 & 104 & PP \\
\hline $1.8 \mathrm{~km} \mathrm{E36N}$ & SAM16 & 23 & - & 32 & - & - & 55 & 8 & 16 & 79 & $\because$ & 79 & - & 21 & 21 & 129 & PP \\
\hline $5.7 \mathrm{~km} \mathrm{~N} 29 \mathrm{E}$ & SAM20 & 18 & - & - & 29 & - & 47 & 2 & 44 & 93 & - & 93 & - & 7 & 7 & 170 & PP \\
\hline $3.3 \mathrm{~km} \mathrm{~N} 22 \mathrm{E}$ & SAM25 & - & - & - & - & 66 & 66 & - & 28 & 94 & - & 94 & 2 & 4 & 6 & 243 & PP \\
\hline $2.1 \mathrm{~km} \mathrm{E32N}$ & & 74 & - & - & - & - & 74 & 13 & 2 & 89 & - & 89 & 6 & 5 & 11 & 184 & 6 \\
\hline $3.5 \mathrm{~km} \mathrm{E} 29 \mathrm{~N}$ & & 57 & - & - & - & - & 57 & 10 & 2 & 69 & - & 69 & 3 & 28 & 31 & 149 & 6 \\
\hline $4.6 \mathrm{~km} \mathrm{E36 \textrm {N }}$ & & 48 & - & - & - & - & 48 & 4 & 13 & 65 & - & 65 & 11 & 24 & 35 & 137 & 6 \\
\hline $2.9 \mathrm{~km} \mathrm{~N} 2 \mathrm{E}$ & & 47 & - & - & - & - & 47 & 12 & 3 & 62 & - & 62 & 3 & 35 & 38 & 133 & 6 \\
\hline $6.4 \mathrm{~km} \mathrm{N14E}$ & & - & - & 72 & - & - & 72 & 7 & 3 & 82 & - & 82 & 6 & 12 & 18 & 334 & 7 \\
\hline
\end{tabular}


Table 4 - Semi-quantitative mineralogical composition (wt.\%) and cation exchange capacity (CEC, meq/100g) of Cyclades Prefecture zeolitic rocks.

\begin{tabular}{|c|c|c|c|c|c|c|c|c|c|c|c|c|c|c|c|c|}
\hline \multirow{2}{*}{ Location } & \multirow{2}{*}{ Sample } & \multicolumn{5}{|c|}{ Microporous minerals } & \multirow{2}{*}{ TMM } & \multirow{2}{*}{ A } & \multirow{2}{*}{$\begin{array}{c}\text { TMM + } \\
\mathbf{A} \\
\end{array}$} & \multicolumn{4}{|c|}{ Non-microporous miner. } & \multirow{2}{*}{ TNM } & \multirow{2}{*}{ CEC } & \multirow{2}{*}{ Ref } \\
\hline & & H-C & Mo & $\mathbf{Z T}$ & Mi & $\mathrm{Cl}$ & & & & $\mathbf{Q z}$ & Tr & Fs & AG & & & \\
\hline \multicolumn{8}{|c|}{ From Kimolos village } & \multicolumn{9}{|c|}{ KIMOLOS ISLAND } \\
\hline $4.0 \mathrm{~km} \mathrm{~W} 5 \mathrm{~N}$ & KIMI & - & 30 & 30 & 15 & - & 45 & - & 45 & - & - & 55 & - & 55 & 96 & PP \\
\hline \multicolumn{8}{|c|}{ From Polyegos village } & \multicolumn{9}{|c|}{ POLYEGOS ISLAND } \\
\hline $1.9 \mathrm{~km} \mathrm{S9W}$ & POL1 & 22 & 44 & 66 & - & 5 & 71 & - & 71 & 5 & - & 24 & - & 29 & 153 & PP \\
\hline $1.7 \mathrm{~km} \mathrm{~S} 5 \mathrm{~W}$ & POL3 & - & 61 & 61 & - & - & 61 & 22 & 83 & 5 & 6 & 6 & - & 17 & 136 & PP \\
\hline \multicolumn{9}{|c|}{ From Adamas village } & \multicolumn{8}{|c|}{ MILOS ISLAND } \\
\hline $\begin{array}{l}6.9 \mathrm{~km} \mathrm{~S} 15 \mathrm{~W} \\
\text { Panagia }\end{array}$ & MIL2 & - & 45 & 45 & - & 7 & 52 & 12 & 64 & 36 & - & & - & 36 & 97 & PP \\
\hline \multicolumn{17}{|c|}{ From Akrotiri village } \\
\hline $0.8 \mathrm{~km} \mathrm{~W}$ & SAN1 & 33 & - & 33 & - & 14 & 47 & 4 & 51 & - & - & 42 & 7 & 49 & 118 & PP \\
\hline $1.0 \mathrm{~km} \mathrm{~W} 26 \mathrm{~S}$ & SAN2 & 57 & 15 & 72 & - & 14 & 86 & 2 & 88 & - & - & 8 & 4 & 12 & 177 & PP \\
\hline $0.8 \mathrm{~km} \mathrm{~N} 34 \mathrm{~W}$ & SAN6 & - & 56 & 56 & - & 4 & 60 & 11 & 71 & 5 & - & 13 & 11 & 29 & 130 & PP \\
\hline
\end{tabular}

\section{Conclusions}

The majority of the Greek zeolitic rock samples contain HEU-type (heulandite-clinoptilolite) zeolite (22 out of 42), while mordenite and analcime were found in fewer samples (6 and 4, respectively). HEU-type + mordenite were found in 7 samples, HEU-type + analcime, HEU-type + phillipsite and chabazite were found in one sample, respectively. The highest contents of HEUtype zeolite (70-91 wt.\%) were mainly found in the areas of Petrota and Pentalofos (Evros Prefecture) and Karlovassi basin (Samos island), while the highest values of analcime content (71 wt.\%) were found in the Samos island. The highest content (24 wt.\%) of amorphous material was found in the mordenitic rocks of Samos island.

The cation exchange capacity (CEC) of zeolitic rocks reaches values up to $285 \mathrm{meq} / 100 \mathrm{~g}$ for analcime-rich (71 wt.\%) tuffs of Samos island, up to $243 \mathrm{meq} / 100 \mathrm{~g}$ for chabazite-rich (66 wt.\%) tuffs of Samos island, $217 \mathrm{meq} / 100 \mathrm{~g}$ for HEU-type rich tuffs of Petrota area ( $89 \mathrm{wt} . \%)$ and Samos island (86 wt.\%), $209 \mathrm{meq} / 100 \mathrm{~g}$ for HEU-type (48wt.\%) + mordenite (26 wt.\%) rich tuffs of Feres area, $170 \mathrm{meq} / 100 \mathrm{~g}$ for HEU-type $(18 \mathrm{wt} \%)$ + Phillipsite $(29 \mathrm{wt} \%)$ rich tuffs of Samos island, $150 \mathrm{meq} / 100 \mathrm{~g}$ for mordenite-rich (64 wt.\%) tuffs of Samos island, and $129 \mathrm{meq} / 100 \mathrm{~g}$ for HEUtype (23 wt.\%) + analcime (32 wt.\%) rich tuffs of Samos island.

The CEC of the zeolitic rocks show positive correlations with the type and the content of zeolites and the microporous minerals (zeolites + micas + clay minerals) + amorphous material. The CEC is mainly affected by the zeolites and to a lesser extent by the other micrporous minerals (micas + clay minerals). The amorphous material may affect the CEC values, depending on their chemistry and despite the lack of crystallinity, the chemical structure of the amorphous materials includes anionic charges, and thus may result to some sorption ability.

\section{References}

Arvanitidis, A., 1998. Northern Greece's industrial minerals: production and enviromental technology developments, Journal of Geochemical Exploration, 62, 217-227. 


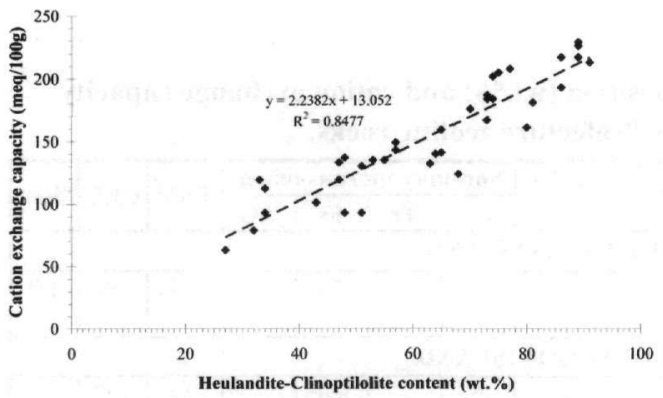

Figure 2 - CEC vs HEU-type zeolite content

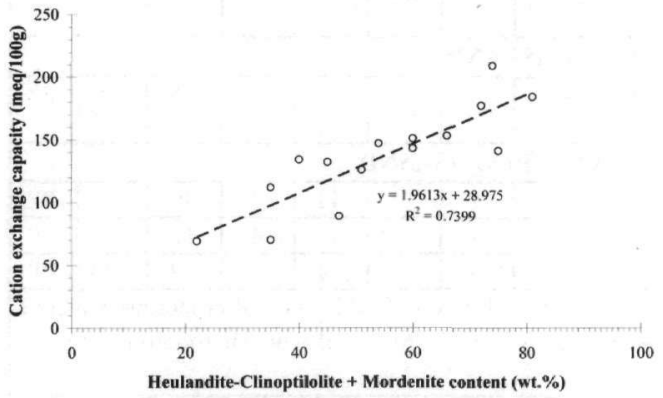

Figure 4-CEC vs HEU-type + mordenite content

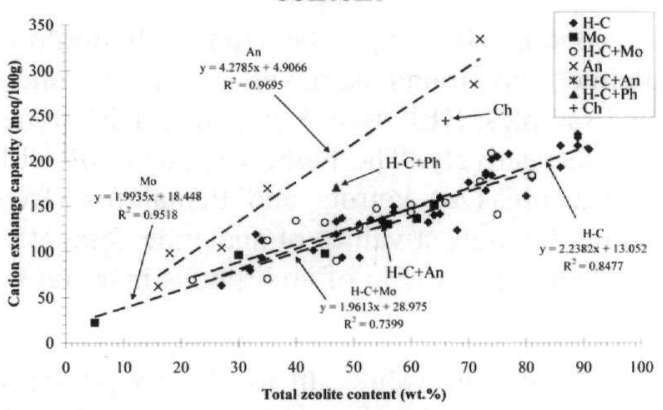

Figure 6-CEC vs total zeolite content

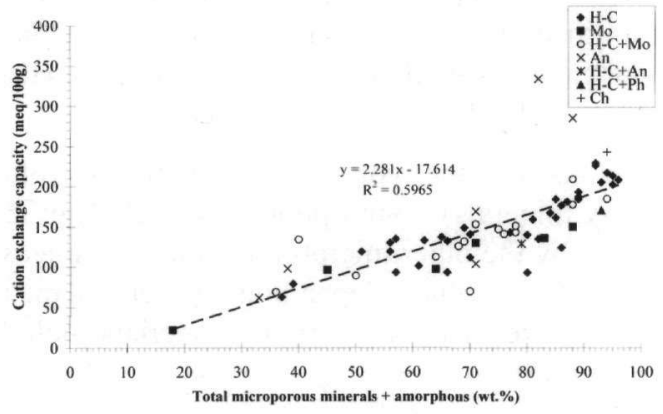

Figure 8 - CEC vs total microporous minerals content + amorphous material

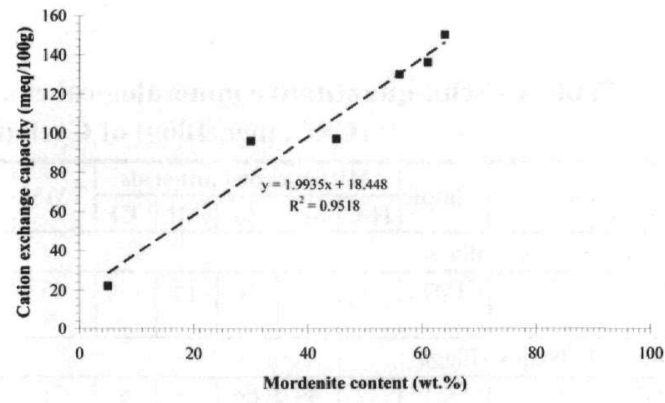

Figure 3 - CEC vs mordenite content

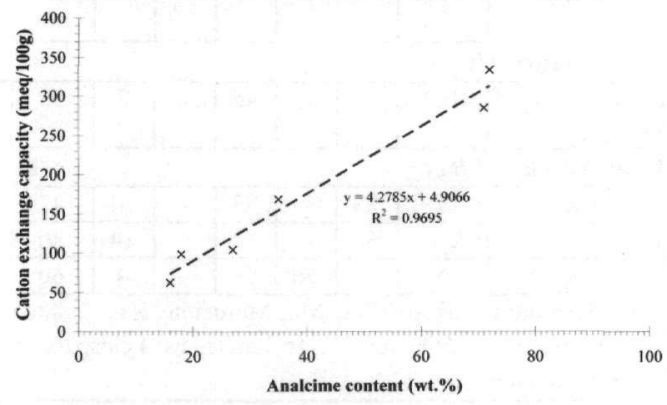

Figure 5-CEC vs analcime content

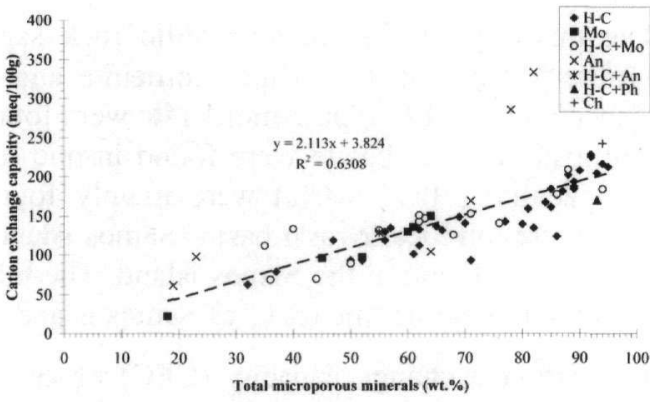

Figure 7 - CEC vs total micropor. minerals content (zeolites + micas + clay minerals) 
Barbieri, M., Castorina, F., Masi, U., Garbarino, C., Nicoletti, M., Kassoli-Fournaraki, A., Filippidis, A., and Mignardi, S., 2001. Geochemical and isotopic evidence for the origin of rhyolites from Petrota (Northern Thrace, Greece) and geodynamic significance, Chemie der Erde, 61, 13-29.

Christidis, G.E., Moraetis, D., Keheyan, E., Akhalbedashvili, L., Kekelidze, N., Gevorkyan, R., Yeritsyan, H., and Sargsyan, H., 2003. Chemical and thermal modification of natural HEUtype zeolitic materials from Armenia, Georgia and Greece, Applied Clay Science, 24, 7991.

Deligiannis, K., Lainas, Th., Arsenos, G., Papadopoulos, E., Fortomaris, P., Kufidis, D., Stamataris, C., and Zygoyiannis, D., 2005. The effect of feeding clinoptilolite on food intake and performance of growing lambs infected or not with gastrointestinal nematodes, Livestock Production Science, 96, 195-203.

Drakoulis, A., Kantiranis, N., Filippidis, A., and Stergiou, A., 2005. The uptake ability of amorphous-rich industrial materials from Milos Island, Proc. $2^{\text {nd }}$ Congr. Econ. Geol.Geochem. Com. of Geol. Soc. Greece, Thessaloniki, 7-9 October, 55-63 (in Greek with English abstract).

Filippidis, A., 1993. New find of moissanite in the Metaxades zeolite-bearing volcaniclastic rocks, Thrace county, Greece, Neues Jahrbuch fur Mineralogie Monatshefte, 11, 521-527.

Filippidis, A., 2005. Improvement and protection of Lake Koronia waters with natural zeolite, Proc. $13^{\text {th }}$ Seminar on Environmental Protection, Thessaloniki, 28 November-1 December, 73-84 (in Greek).

Filippidis, A., and Kassoli-Fournaraki, A., 2000a. Environmental uses of natural zeolites from Evros district, Thrace, Greece, Proc. $5^{\text {th }}$ Int. Conf. on Environmental Pollution, Thessaloniki, 28 August-1 September, 149-155.

Filippidis, A., and Kassoli-Fournaraki, A., 2000b. The possibility of using Greek natural zeolites for the restoration of the mined land in the Lignite Center of Ptolemais-Aminteo, Macedonia, Greece, Proc. $1^{\text {st }}$ Congr., Econ. Geol.-Geochem. Com. Of GSG, Kozani, 12-13 February, 506-515. (in Greek with English abstract)

Filippidis, A., and Kassoli-Fournaraki, A., 2002. Management of aquatic ecosystems using Greek natural zeolites, Proc. $12^{\text {th }}$ Seminar on Environmental Protection, Thessaloniki, 2-5 December, 75-82. (in Greek)

Filippidis, A., and Kantiranis, N., 2005. Industrial, agricultural and environmental uses of the natural zeolites of Thrace, Bull. Geol. Soc. Greece, 37, 90-101. (in Greek with English summary)

Filippidis, A., and Kantiranis, N., 2007. Experimental neutralization of lake and stream waters from N. Greece using domestic HEU-type rich natural zeolitic material, Desalination, 213, 47-55.

Filippidis, A., Kassoli-Fournaraki, A., Charistos, D., and Tsirambides, A., 1997. Greek zeolites, a material for removing trace elements and neutralizing the $\mathrm{pH}$ of water, Proc. $4^{\text {th }}$ Hydrogeological Congr., Thessaloniki, 14-16 November, 539-546. (in Greek with English abstract)

Filippidis, A., Kantiranis, N., Drakoulis, A., and Vogiatzis, D., 2005. Quality, pollution, treatment and management of drinking, waste, underground and surface waters, using analcime-rich zeolitic tuff from Samos island, Hellas, Proc. $7^{\text {th }}$ Hellenic Hydrogeology Conf., Athens, 4-6 October, 219-224. 
Filippidis, A., Kantiranis, N., Drakoulis, A., and Vogiatzis, D., 2006. Improvement and protection of lake Koronia using natural zeolite, Proc. $2^{\text {nd }}$ Congr. A.U.TH. Environment Council, Thessaloniki, 1-4 June, 273-279. (in Greek with English summary)

Fragoulis, D., Chaniotakis, E., and Stamatakis, M.G., 1997. Zeolitic tuffs of Kimolos island, Aegean sea, Greece and their industrial potential, Cement and Concrete Research, 27(6), 889-905.

Haidouti, C., 1997. Inactivation of mercury in contaminated soils using natural zeolites, The Science of the Total Environment, 208, 105-109.

Hall, A., and Stamatakis, M.G., 1992. Ammonium in zeolitized tuffs of the Karlovassi basin, Samos, Greece, Canadian Mineralogist, 30, 423-430.

Hall, A., Stamatakis, M.G., and Walsh, J.N., 1994. Ammonium enrichment associated with diagenetic alteration in Tertiary pyroclastic rocks from Greece, Chemical Geology, 118, 173-183.

Hall, A., Stamatakis, M.G., and Walsh, J.N., 2000. The Pentalofos zeolitic tuff formation: A giant ion-exchange column, Annales Geologiques des Pays Helleniques, 38, 175-192.

Holmes, D.A., 1994. Zeolites. In D.D. Carr (ed.), Industrial Minerals and Rocks. 1129-1158, Ann Arbor, Michigan, Braun-Brumfield Inc., 1196.

Inglezakis, V.J., and Grigoropoulou, H.P., 2003. Modeling of ion exchange of $\mathrm{Pb}^{2+}$ in fixed beds of clinoptilolite, Microporous and Mesoporous Materials, 61, 273-282.

Inglezakis, V.J., Zorpas, A.A., Loizidou, M.D., and Grigoropoulou, H.P., 2003. Simultaneous removal of metals $\mathrm{Cu}^{2+}, \mathrm{Fe}^{3+}$ and $\mathrm{Cr}^{3+}$ with anions $\mathrm{SO}_{4}^{2-}$ and $\mathrm{HPO}_{4}^{2-}$ using clinoptilolite, Microporous and Mesoporous Materials, 61, 167-171.

Kantiranis, N., Stamatakis, M., Filippidis, A., and Squires, C., 2004a. The uptake ability of the clinoptilolitic tuffs of Samos island, Greece, Bull. Geol. Soc. Greece, 36, 89-96.

Kantiranis, N., Stergiou, A., Filippidis, A., and Drakoulis, A., 2004b. Calculation of the percentage of amorphous material using PXRD patterns, Bull. Geol. Soc. Greece, 36, 446-453. (in Greek with English abstract)

Kantiranis, N., Chrissafis, C., Filippidis, A., and Paraskevopoulos, K.M., 2006. Thermal distinction of HEU-type mineral phases contained in Greek zeolite-rich volcaniclastic tuffs, European Journal of Mineralogy, 18(4), 509-516.

Kassoli-Fournaraki, A., Stamatakis, M., Hall, A., Filippidis, A., Michailidis, K., Tsirambides, A., and Koutles, Th., 2000. The Ca-rich clinoptilolite deposit of Pentalofos, Thrace, Greece. In C. Colella and Mumpton (eds), Natural Zeolites for the Third Millennium. 193-202, Napoli, De Frede, $481 \mathrm{pp}$

Katranas, T.K., Vlessidis, A.G., Tsiatouras, V.A., Triantafyllidis, K.S., and Evmiridis, N.P., 2003. Dehydrogenation of propane over natural clinoptilolite zeolites, Microporous and Mesoporous Materials, 61, 189-198.

Kirov, G.N., Filippidis, A., Tsirambidis, A., Tzvetanov, R.G., and Kassoli-Fournaraki, A., 1990. Zeolite-bearing rocks in Petrota area (Eastern Rhodope Massif, Greece), Geologica Rhodopica, 2, 500-511.

Kitsopoulos, K.P., 1997a. The genesis of a mordenite deposit by hydrothermal alteration of pyroclastics on Polyegos Island, Greece, Clays and Clay Minerals, 45(5), 632-648. 
Kitsopoulos, K.P., 1997b. Comparison of the methylene blue absorption and the ammonium acetate saturation methods for determination of CEC values of zeolite-rich tuffs, Clay Minerals, 32, 319-322.

Kitsopoulos, K., and Dunham, A., 1994. Application of zeolitic volcanic tuffs from Greece (Lefkimi-Dadia, Metaxades, and Santorini island, Greece) as pozzolanic materials, Bull. Geol. Soc. Greece, 30(3), 323-332.

Kitsopoulos, K.P., and Dunham, A.C., 1996. Heulandite and mordenite-rich tuffs from Greece: A potential source for pozzolanic materials, Mineralium Deposita, 31, 576-583.

Koutles, Th., Kassoli-Fournaraki, A., Filippidis, A. and Tsirambides, A., 1995. Geology and geochemistry of the Eocene zeolitic-bearing volcaniclastic sediments of Metaxades, Thrace, Greece, Estudios Geologicos, 51, 19-27.

Krestou, A., Xenidis, A., and Panias, D., 2003. Mechanism of aqueous uranium (VI) uptake by natural zeolitic tuff, Minerals Engineering, 16, 1363-1370.

Kyriakis, S.C., Papaioannou, D.S., Alexopoulos, C., Polizopoulou, Z., Tzika, E.D., and Kyriakis, C.S., 2002. Experimental studies on safety and efficacy of the dietary use of a clinoptiloliterich tuff in sows: a review of recent research in Greece, Microporous and Mesoporous Materials, 51, 65-74.

Marantos, I.A., 2004. Study of the Tertiary volcanic rocks alteration in the Feres basin of Evros Prefecture, emphasizing on the genesis of zeolites and their possible applications, $P h D$ Thesis, Technical University of Crete, Chania, 264pp. (in Greek with English summary)

Marantos, I., and Perdikatsis, V., 1994. Study of mineralogy, dehydration / rehydration, cation exchange capacity of zeolitic tuffs of Petrota - Pentalofos area (Orestias basin) Evros county, Bull. Geol. Soc. Greece, 30(3), 311-321. (in Greek with English abstract)

Marantos, I., Koshiaris, G., Karantasi, S., and Gregoriadis, G., 1989. A study on zeolitic alteration of Tertiary pyroclastics from Metaxades area, Evros county, Greece, Bull. Geol. Soc. Greece, 23(2), 443-450. (in Greek with English abstract)

Marantos, I., Kosharis, G., Perdikatsis, V., Karantassi, S., Michael, C., and Papadopoulos, P., 1997. A preliminary study on the zeolitic tuffs in the Komotini-Sappes, Tertiary basin, W. Thrace, NE Greece. In G. Kirov, L. Filizova and O. Petrov (eds), Natural Zeolites Sofia'95, 276-281, Sofia-Moscow, Pensoft publ., 300pp.

Marantos, I., Kosharis, G., Perdikatsis, V., Karantassi, S., Kaloeidas, V., and Malami, C., 2001. Evaluation of altered pyroclastics from Rhodope Prefecture, Thrace, Greece as constituents of pozzolanic cements, Bull. Geol. Soc. Greece, 34(3), 1155-1162. (in Greek with English abstract)

Misaelides, P., Godelitsas, A., and Filippidis, A., 1994. The caesium uptake by the zeoliferous rocks of Metaxades area (Evros, Thrace), Proc. 15 th Panhellenic Chemistry Congr. Thessaloniki, 6-10 December, A 218-221. (in Greek with English summary)

Misaelides, P., Godelitsas, A., and Filippidis, A., 1995a. The use of zeoliferous rocks from Metaxades-Thrace, Greece, for the removal of caesium from aqueous solutions, Fresenius Environmental Bulletin, 4, 227-231.

Misaelides, P., Godelitsas, A., Filippidis, A., Charistos, D., and Anousis, I., 1995b. Thorium and uranium uptake by natural zeolitic materials, The Science of the Total Environment, $173 / 174,237-246$.

Moirou, A., Xenidis, A., and Paspaliaris, I., 2001. Stabilization Pb, Zn, and Cd- contaminated soil by means of natural zeolites, Soil and Sediment Contamination, 10(3), 251-267. 
Papadopoulos, A., Fatta, D., Parperis, K, Mentzis, A., Haralambous, K.J., and Loizidou, M., 2004. Nickel uptake from a wastewater stream produced in a metal finishing industry by combination of ion-exchange and precipitation methods, Separation and Purification Technology, 39, 181-188.

Papaioannou, D.S., Kyriakis, S.C., Papasteriadis, A., Roumbies, N., Yannakopoulos, A., and Alexopoulos, C., 2002a. A field study on the effect of in-feed inclusion of a natural zeolite (clinoptilolite) on health status and performance of sows/gilts and their litters, Research in Veterinary Science, 72, 51-59.

Papaioannou, D.S., Kyriakis, S.C., Papasteriadis, A., Roumbies, N., Yannakopoulos, A., and Alexopoulos, C., 2002b. Effect of in-feed inclusion of a natural zeolite (clinoptilolite) on certain vitamin, macro and trace element concentrations in the blood, liver and kidney tissues of sows, Research in Veterinary Science, 72, 61-68.

Pe-Piper, G., and Tsolis-Katagas, P., 1991. K-rich mordenite from Late Miocene rhyolitic tuffs, Island of Samos, Greece, Clays and Clay Minerals, 39(3), 239-247.

Perraki, Th., and Orfanoudaki, A., 2004. Mineralogical study of zeolites from Pentalofos area, Thrace, Greece, Applied Clay Science, 25, 9-16.

Perraki, Th., Kakali, G., and Kontoleon, F., 2003. The effect of natural zeolites on the early hydration of Portland cement, Microporous and Mesoporous Materials, 61, 205-212.

Sikalidis, C.A., 1998. Heavy metals and toxic elements removal from contaminated waters by clay minerals and zeolite bearing rocks. Proc. Fourth Int. Conf. on Environmental Pollution, Thessaloniki, 1 September, 102-110.

Skarpelis, N., Marantos, I., and Christidis, G., 1993. Zeolites in Oligocene volcanic rocks, DadiaLefkimi area, Thrace, Northern Greece: Mineralogy and cation exchange properties, Bull. Geol. Soc. Greece, 28(2), 305-315.

Stamatakis, M.G., 1989a. Authigenic silicates and silica polymorphs in the Miocene salinealkaline deposits of the Karlovassi basin, Samos, Greece, Economic Geology, 84, 788-798.

Stamatakis, M.G., 1989b. A boron-bearing potassium feldspar in volcanic ash and tuffaceous rocks from Miocene lake deposits, Samos Island, Greece, American Mineralogist, 74, 230 235.

Stamatakis, M.G., Hall, A., and Hein, J.R., 1996. The zeolite deposits of Greece, Mineralium Deposita, 31, 473-481.

Stamatakis, M.G., Hall, A., Lutat, U., and Walsh, J.N., 1998. Mineralogy, origin and commercial value of the zeolite-rich tuffs in the Petrota-Pentalofos area, Evros County, Greece, Estudios Geologicos, 54, 3-15.

Stamatakis, M., Koukouzas, N., Vassilatos, Ch., Kamenou, E., and Samantouros, K., 2001. The zeolites from Evros region, Northern Greece: A potential use as cultivation substrate in hydroponics, Acta Horticulturae, 548, 93-103.

Symeopoulos, B., Soupioni, M., Misaelides, P., Godelitsas, A., and Barbayiannis, N., 1996. Neodymium sorption by clay minerals and zeoliferous rocks, Journal of Radioanalytical and Nuclear Chemistry, Letters, 212(6), 421-429.

Tserveni-Gousi, A.S., Yannakopoulos, A.L., Katsaounis, N.K., Filippidis, A., and KassoliFournaraki, A., 1997. Some interior egg characteristics as influenced by addition of Greek clinoptilolitic rock material in the hen diet, Archiv fur Geflugelkunde, 61, 291-296.

Tsirambides, A.E., 1991. Study of zeoliferous volcaniclastic sediments of Metaxades Evros, Mineral Wealth, 72, 41-48. (in Greek with English summary) 
Tsirambides, A., Kassoli-Fournaraki, A., Filippidis, A., and Soldatos, K., 1989. Preliminary results on clinoptilolite-containing volcaniclastic sediments from Metaxades, NE Greece, Bull. Geol. Soc. Greece, 23, 451-460.

Tsirambides, A., Filippidis, A., and Kassoli-Fournaraki, A., 1993. Zeolitic alteration of Eocene volcaniclastic sediments at Metaxades, Thrace, Greece, Applied Clay Science, 7, 509-526.

Tsolis-Katagas, P., and Katagas, C., 1989. Zeolites in pre-caldera pyroclastic rocks of the Santorini volcano, Aegean sea, Greece, Clays and Clay Minerals, 37(6), 497-510.

Tsolis-Katagas, P., and Katagas, C., 1990. Zeolitic diagenesis of Oligocene pyroclastic rocks of the Metaxades area, Thrace, Greece, Mineralogical Magazine, 54, 95-103.

Vlessidis, A.G., Triantafillidis, C.S., and Evmiridis, N.P., 2001. Removal and recovery of pphenylenediamines developing coumpounds from photofinishing lab washwater using clinoptilolite tuffs from Greece, Water Research, 35(6), 1603-1608.

Warchol, J., Misaelides, P., Petrus, R., and Zamboulis, D., 2006. Preparation and application of organo-modified zeolitic material in the removal of chromates and iodides, Journal of Hazardous Materials, B137, 1410-1416.

Yannakopoulos, A.L., Tserveni-Gousi, A.S., and Christaki, E., 1998. Effect of natural zeolite on yolk:albumen ratio in hen eggs, British Poultry Science, 39, 506-510.

Yannakopoulos, A., Tserveni-Gousi, A., Kassoli-Fournaraki, A., Tsirambides, A., Michailidis, K., Filippidis, A., and Lutat, U., 2000. Effects of dietary clinoptilolite-rich tuff on the performance of growing-finishing pigs. In C. Colella and Mumpton (eds), Natural Zeolites for the Third Millennium. 471-481, Napoli, De Frede, 481pp

Zorpas, A.A., Constantinides, T., Vlyssides, A.G., Haralambous, I., and Loizidou, M., 2000a. Heavy metal uptake by natural zeolite and metals partitioning in sewage sludge compost, Bioresource Technology, 72, 113-119.

Zorpas, A.A., Kapetanios, E., Zorpas, G.A., Karlis, P., Vlyssides, A., Haralambous, I., and Loizidou, M., 2000b. Compost produced from organic fraction of municipal solid waste, primary stabilized sewage sludge and natural zeolite, Journal of Hazardous Materials, B77, 149-159. 